\title{
The effect of typhoon on particulate organic carbon flux in the southern East China Sea
}

\author{
C.-C. Hung ${ }^{1}$, G.-C. Gong ${ }^{1}$, W.-C. Chou ${ }^{1}$, C. -C. Chung ${ }^{1,2}$, M.-A. Lee $^{3}$, Y. Chang ${ }^{3}$, H.-Y. Chen ${ }^{4}$, S.-J. Huang ${ }^{4}$, \\ Y. Yang ${ }^{5}$, W.-R. Yang ${ }^{5}$, W.-C. Chung ${ }^{1}$, S.-L. Li ${ }^{1}$, and E. Laws ${ }^{6}$ \\ ${ }^{1}$ Institute of Marine Environmental Chemistry and Ecology, National Taiwan Ocean University, Keelung, 20224, Taiwan \\ ${ }^{2}$ Center for Marine Bioenvironment and Biotechnology, National Taiwan Ocean University, Keelung, 20224, Taiwan \\ ${ }^{3}$ Department of Environmental Biology and Fisheries Science, National Taiwan Ocean University, Keelung, 20224, Taiwan \\ ${ }^{4}$ Department of Marine Environmental Informatics, National Taiwan Ocean University, Keelung, 20224, Taiwan \\ ${ }^{5}$ Taiwan Ocean Research Institute, National Applied Research Laboratories, Taipei, Taiwan \\ ${ }^{6}$ Department of Environmental Sciences, School of the Coast and Environment, Louisiana State University, Baton Rouge, \\ LA 70803, USA
}

Received: 16 April 2010 - Published in Biogeosciences Discuss.: 19 May 2010

Revised: 16 September 2010 - Accepted: 21 September 2010 - Published: 4 October 2010

\begin{abstract}
Severe tropical storms play an important role in triggering phytoplankton blooms, but the extent to which such storms influence biogenic carbon flux from the euphotic zone is unclear. In 2008, typhoon Fengwong provided a unique opportunity to study the in situ biological responses including phytoplankton blooms and particulate organic carbon fluxes associated with a severe storm in the southern East China Sea (SECS). After passage of the typhoon, the sea surface temperature (SST) in the SECS was markedly cooler $\left(\sim 25\right.$ to $26^{\circ} \mathrm{C}$ ) than before typhoon passage $\left(\sim 28\right.$ to $\left.29^{\circ} \mathrm{C}\right)$. The POC flux 5 days after passage of the typhoon was $265 \pm 14 \mathrm{mg} \mathrm{C} \mathrm{m}^{-2} \mathrm{~d}^{-1}$, which was $\sim 1.7$-fold that (140-180 $\mathrm{mg} \mathrm{C} \mathrm{m}^{-2} \mathrm{~d}^{-1}$ ) recorded during a period (June-August, 2007) when no typhoons occurred. A somewhat smaller but nevertheless significant increase in POC flux (224-225 $\mathrm{mg} \mathrm{C} \mathrm{m}^{-2} \mathrm{~d}^{-1}$ ) was detected following typhoon Sinlaku which occurred approximately 1 month after typhoon Fengwong, indicating that typhoon events can increase biogenic carbon flux efficiency in the SECS. Remarkably, phytoplankton uptake accounted for only about $5 \%$ of the nitrate injected into the euphotic zone by typhoon Fengwong. It is likely that phytoplankton population growth was constrained by a combination of light limitation and grazing pressure. Modeled estimates of new/export production were remarkably consistent with the average of new and export production following typhoon Fengwong. The same model
\end{abstract}

Correspondence to: C.-C. Hung (cchung@ntou.edu.tw) suggested that during non-typhoon conditions approximately half of the export of organic carbon occurs via convective mixing of dissolved organic carbon, a conclusion consistent with earlier work at comparable latitudes in the open ocean.

\section{Introduction}

Recent research has shown that typhoons (severe tropical storms also referred to as tropical cyclones or hurricanes) can cause marked cooling of the sea surface, enhance nutrient pumping and result in phytoplankton blooms along storm paths of the typhoon and in adjacent areas (Babin et al., 2004; Bates et al., 1998; Chang et al., 1996; Chang et al., 2008; Lin et al., 2003; Shang et al., 2008; Walker et al., 2005; Zheng and Tang, 2007). Previous studies of typhoon induced phytoplankton blooms have been based largely on satellite remote sensing data, but it can often be difficult to obtain clear ocean color images during or shortly after typhoon passages because of extensive cloud cover. Sea-based measurements of pre- and post-typhoon phytoplankton biomass and biological activity are also limited because of the dangers inherent in field work associated with typhoon events. Consequently, in situ field observations on the effects of typhoons on biological processes are rare (Chang et al., 1996; Chen et al., 2003; Shiah et al., 2000; Zheng and Tang, 2007) and no reports of the effects of typhoon passage on ocean biogeochemistry, especially carbon export fluxes measured using floating sediment traps, have appeared.

Published by Copernicus Publications on behalf of the European Geosciences Union. 
The upwelling of subsurface water on the shelf-break of the SECS has long been observed (Chen et al., 1990; Gong et al., 1995; Liu et al., 1992). The wax and wane of the outcrop of cool upwelled water were attributed to the inflow of the Taiwan Strait water (Gong et al., 1995), or an influence of the strong northeast monsoon in winter (Chuang and Liang, 1994; Gong et al., 1995). Recently, Wu et al. (2008) and Chang et al. (2009) reported a remarkable seasonal variability of this upwelling at depths of $100 \mathrm{~m}$ or more below the surface in summer, but such upwelling was weak in winter. In addition to such factors, typhoons may also enhance cooling in the SECS following passage of a typhoon through an adjacent region (Chang et al., 2008; Tsai et al., 2008). Tsai et al. (2008) reported that a typhoon induced significant upper water column cooling off northeastern Taiwan. Chang et al. (2008) reported that upwelled water persisted in the SECS for more than a week after a typhoon resulting in a phytoplankton bloom in the shelf region.

Several studies (Bates et al., 1998; Lin et al., 2003; Walker et al., 2005; Zhao et al., 2008; Zheng and Tang 2007) have inferred that large quantities of nutrients were carried to the ocean surface resulting in enhanced phytoplankton biomass (even phytoplankton blooms) in the open ocean and coastal waters several days after a typhoon event. However, the cited reports were based on study of satellite images, and the reported phytoplankton biomass (e.g. usually estimated by using empirical band ratio algorithm OC4) has seldom been confirmed by in situ measurements. Thus, Shang et al. (2008) indicated with caution that dissolved organic matter and detritus could significantly affect detected chlorophyll (chl- $a$ ) values near the coast of the northern South China Sea. The study area of Shang et al. (2008) was adjacent to the mouth of the Mekong River, which may discharge runoff containing a high concentration of chromophoric dissolved organic matter. However, no large river was located near the study area, and the satellite ocean color data are thus likely to accurately represent sea conditions, being unaffected by influx of terrestrial materials. In addition, they are supported by ship-based measurements and, therefore, are included in this study as an important source of information.

The flux of biogenic carbon from the euphotic zone of the ocean to depth is one of the main controls on the $\mathrm{CO}_{2}$ partial pressure in the atmosphere. Therefore, measurement of this POC flux is very important for understanding the global carbon cycle and its response to climate change (Emerson et al., 1997). The flux of particulate organic carbon (POC) from the euphotic zone after the passage of a typhoon is poorly understood because typhoons form in remote regions of the open ocean, and sea-based experiments are difficult to conduct due to strong winds and high waves. Typhoons Fengwong and Sinlaku passed through the SECS during the summer of 2008, and in the following 4-7 days of each typhoon we had a unique opportunity to conduct sea-based investigations in the affected area of the SECS. The main objective of the study was to better understand the effect of typhoon

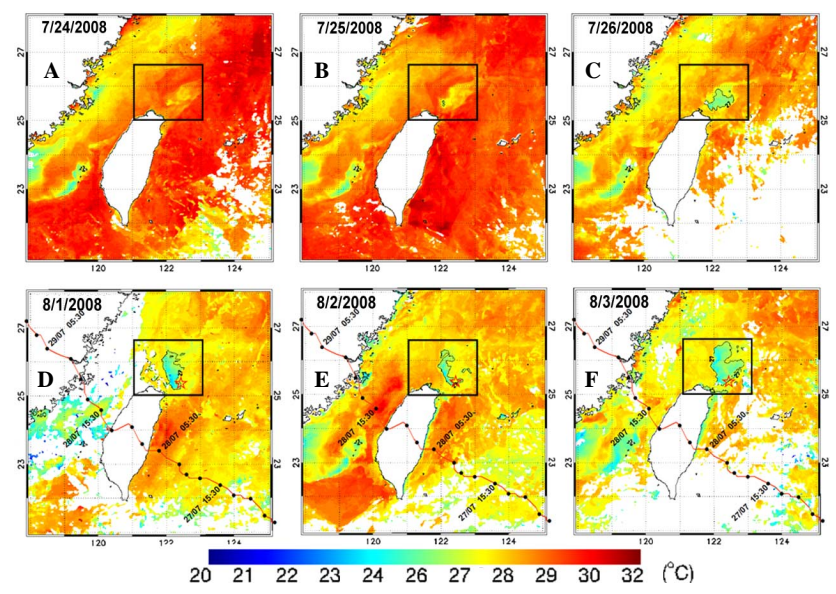

Fig. 1. Study area (blue box, sampling location: a red star) and track (red line in panel D) of typhoon Fengwong in the southern East China Sea. AVHRR satellite images on 24, 25 and 26 before the typhoon and 1, 2 and 3 August after the typhoon. The area of cold water patch (e.g. SST $<27^{\circ} \mathrm{C}$ ) shown in the blue box on 24 July (A) is significantly smaller than that on 2 August (E). The red lines represent the typhoon moving track of Fengwong.

Fengwong on POC flux in the euphotic zone using floating sediment traps. In addition, we conducted field observations of vertical profiles of temperature, salinity, density, photosynthetically active radiation (PAR), nitrate concentration and chl- $a$ concentration in efforts to interpret possible mechanisms affecting POC flux after the passage of typhoon Fengwong in August 2008. Furthermore, we also measured POC fluxes 5 and 7 days after typhoon Sinlaku passed over Taiwan on 13-14 September 2008, but obtained no vertical hydrographic data on either occasion.

\section{Materials and methods}

Sampling was conducted in the SECS, in an area approximately $70 \mathrm{~km}$ northeast of Taiwan $\left(25.40^{\circ} \mathrm{N}, 122.45^{\circ} \mathrm{E}\right.$, Fig. 1), from the R/V Ocean Researcher II (OR II). Five cruises were conducted: one each in June and $\mathrm{Au}-$ gust 2007 (non-typhoon periods), one in August 2008 (23 August 2008) after the passage of typhoon Fengwong, and one each on 19 and 21 September 2008 after the passage of typhoon Sinlaku. Data on wind speed during the typhoons were provided by the Central Weather Bureau of Taiwan. Salinity, temperature, density and beam attenuation (e.g. transmissometer profiles) were recorded using a SeaBird model SBE9/11 plus conductivity/temperature/depth (CTD) recorder and a transmissometer (Wet Labs). The mean downwelling attenuation coefficient $\left(K_{\mathrm{PAR}}\right)$ was obtained from a linear regression of the log-transformed underwater irradiance profiles which were measured with a PAR scalar quantum irradiance sensor (Chelsea Technologies Group 
Ltd, UK). The depth of the euphotic depth (EZ) was defined as the depth of $1 \%$ surface light penetration $\left(=4.605 / K_{\mathrm{PAR}}\right)$.

The concentrations of nitrate $\left(\mathrm{NO}_{3}\right)$ and chlorophyll- $a$ (chl- $a$ ) at depths of $0,10,25,50,75$, and $100 \mathrm{~m}$ were determined according to Gong et al. (2000). The method of chl- $a$ determination is similar to NASA protocols (Mueller and Austin, 1995). In brief, the chl- $a$ samples were collected by filtering $500 \mathrm{ml}$ of seawater through a GF/F filter and stored at $-20^{\circ} \mathrm{C}$ until analysis. Concentration of chl- $a$ on the GF/F filter was extracted by acetone and determined according to standard procedures using a Turner Designs 10AU-005 fluorometer by the non-acidification method (Gong et al., 2000). Sinking particles were collected using a drifting sediment trap array, which consisted of six cylindrical plastic core tubes $(6.8 \mathrm{~cm}$ diameter) with honeycomb baffles covering the trap mouths (Hung et al., 2003, 2004; Hung and Gong, 2007). The array was attached to an electric surface buoy with a global positioning system (GPS) antenna (TGB-500, TAIYO, Japan). The trap tubes, filled with filtered seawater $(<0.5 \mu \mathrm{m})$, were deployed daily for 4 to $6 \mathrm{~h}$ at a depth of $70 \mathrm{~m}$. Aliquots from sediment traps were filtered through $1 \mu \mathrm{m}$ quartz filters (Whatman QMA) as described in Hung et al. (2009). The swimmers evident with a microscope on the filters were carefully removed using forceps. After fuming the filters with $\mathrm{HCl}$, the POC on the filters was measured using an elemental analyzer (Elementa, Vario EL-III, Germany). In addition to measurements associated with the passage of typhoon Fengwong, we also analyzed POC flux 5 and 7 days after typhoon Sinlaku, but no vertical hydrographic data on either occasion were collected.

The sea surface temperatures (SST) from $25.2-25.7 \mathrm{~N}^{\circ}$ and 122.1 to $122.6 \mathrm{E}^{\circ}$ were estimated (resolution $1.1 \mathrm{~km}$ ) before and after passage of typhoons Fengwong and Sinlaku using AVHRR (Advanced Very High Resolution Radiometer) infrared sensors under cloud-free conditions. The AVHRR data were processed at the National Taiwan Ocean University ground station. SST estimates and atmospheric attenuation correction were based on the multi-channel SST (MCSST) algorithm (McClain, et al., 1985). Comparisons of the accuracy of AVHRR-derived SSTs with in situ data were based on the method of Lee et al. (2005). The root mean square errors and biases for satellite-derived SSTs were $0.65^{\circ} \mathrm{C}$ and $0.01^{\circ} \mathrm{C}$ from 961 match-up data sets (Lee et al., 2005), respectively. MODIS ocean color data was generated from archived Level 2 version of NASA, then the chl- $a$ value was estimated by averaging both Terra and Aqua derived data. For SeaWiFS data, this sensor was out of working order during July 2008, and images were clouded during September 2008. Therefore, we could not generate chl- $a$ data from SeaWiFS to compare with MODIS data. Primary productivity (PP) was derived using an empirical MODIS chl$a$-temperature algorithm based on a function of maximum carbon fixation within a water column, sea surface photosynthetically active radiation, euphotic zone depth (depth of $1 \%$ surface light penetration), chlorophyll concentration and photoperiod (Behrenfeld and Falkowski, 1997) or by the ${ }^{14} \mathrm{C}$ assimilation method (Parsons et al., 1984; Gong et al., 1999, 2003). In brief, water samples for the PP measurements were prescreened through a $200-\mu \mathrm{m}$ mesh and dispensed into acidcleaned polycarbonate carboy (10 L, Nalgene). Each subsample was inoculated with $10 \mu \mathrm{Ci} \mathrm{NaH}{ }^{14} \mathrm{CO}_{3}$ before incubation. The $\mathrm{P}^{\mathrm{B}}-\mathrm{E}$ (photosynthetic-irradiance) curve at each sampling depth was determined using a seawater-cooled incubator illuminated for two hours with artificial light. PP at each depth could then be calculated with the parameters from the $\mathrm{P}^{\mathrm{B}}$-E curve. The detailed procedures can be found in Gong et al. (2003). New production (NP) was derived using the model of Laws et al. (2000) based on ef (= export flux (or NP)/PP) ratios and a function of temperature, euphotic zone depth and primary production (the detailed information on the model can be found at http://usjgofs.whoi.edu/mzweb/ syndata.html\#Biogeochemical.

\section{Results}

\subsection{Variation in surface hydrographic settings before and after typhoon passage}

Typhoon Fengwong was a category 2 typhoon (sustained winds $=43 \mathrm{~m} \mathrm{~s}^{-1}$, wind gusts $=53 \mathrm{~m} \mathrm{~s}^{-1}$ ) that traveled at a speed of $4.4-4.7 \mathrm{~m} \mathrm{~s}^{-1}$ on 26-27 July 2008 and 3.3$3.8 \mathrm{~m} \mathrm{~s}^{-1}$ on $28-29$ July 2008 (Fig. 1). The typhoon made landfall on the eastern side of Taiwan on 28 July 2008 and affected the island for $10 \mathrm{~h}$. The AVHRR-derived SSTs in the study region before (24-26 July) and after (1-3 August) the typhoon are shown in Fig 1. The daily average SST value for the study area $\left(25.2-25.7 \mathrm{~N}^{\circ}\right.$ and 122.1 to $\left.122.6 \mathrm{E}^{\circ}\right)$ is shown in Fig. 2a. It is noteworthy that the average SST continually decreased from $28.9^{\circ} \mathrm{C}$ on 24 July (before the typhoon) to $25.7^{\circ} \mathrm{C}$ on 4 August 2008 (after the typhoon) and then increased to $29^{\circ} \mathrm{C}$ on 15 August (Fig. 2a). Furthermore, the area of the cold water patch (defined as SST $<27^{\circ} \mathrm{C}$ ) increased gradually from $118 \mathrm{~km}^{2}$ on 24 July to $14379 \mathrm{~km}^{2}$ on 5 August (Fig. 2b). Similar surface water cooling phenomena were also found after the passage of typhoon Sinlaku. Sinlaku was a category 3 (sustained winds $\sim 51 \mathrm{~m} \mathrm{~s}^{-1}$ ) typhoon in the western Pacific. Its sustained winds decreased to $>33 \mathrm{~m} \mathrm{~s}^{-1}$ as it approached eastern Taiwan. The average daily SST decreased continuously from $28.6^{\circ} \mathrm{C}$ on 7 September to $26.5^{\circ} \mathrm{C}$ on 22 September 2008 (Fig. 2a) and quickly rebounded to $27^{\circ} \mathrm{C}$ during 23-27 September. The maximum area $\left(17876 \mathrm{~km}^{2}\right.$, on 17 September) of the cold water patch $\left(\mathrm{SST}<27^{\circ} \mathrm{C}\right)$ caused by typhoon Sinlaku was greater than that resulting from typhoon Fengwong (Fig. 2b). The area of the cold water patch quickly decreased to $1378 \mathrm{~km}^{2}$ on 18 September and rebounded to $8056 \mathrm{~km}^{2}$ on 22 September. The SST values of the SECS nonetheless showed water cooling after each typhoon. 

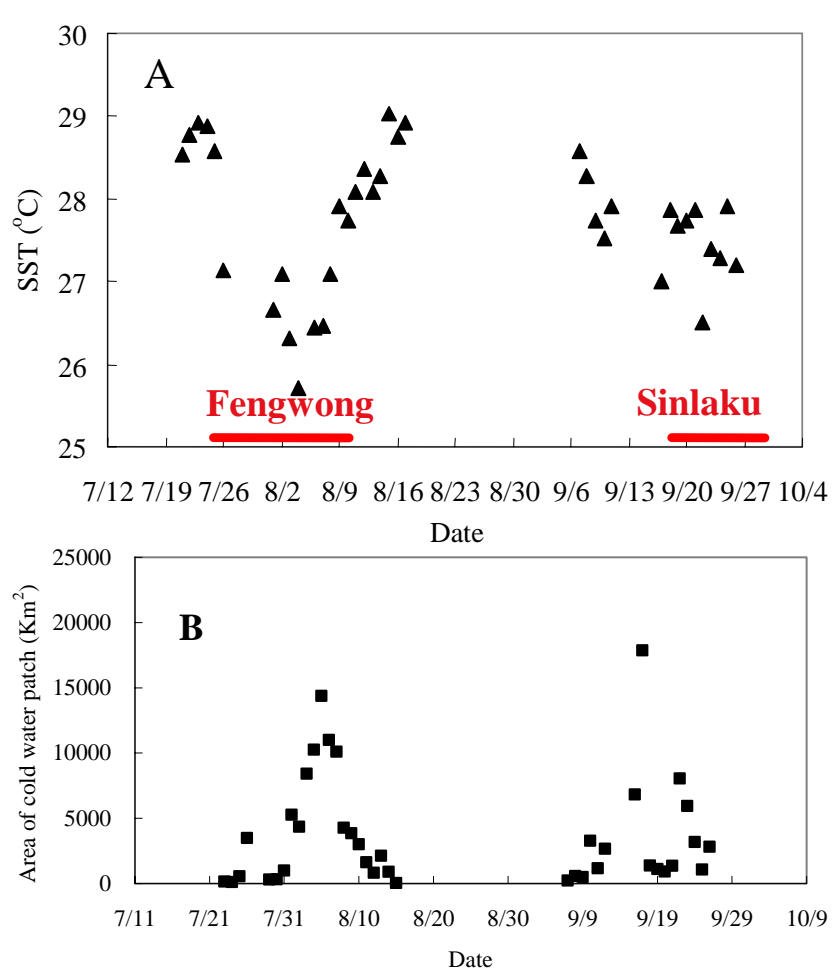

Fig. 2. (A) Sea surface temperature (SST) and (B) the area of cold water patch (e.g. SST $<27^{\circ} \mathrm{C}$ ) in the southern East China Sea (between $25.2-25.7 \mathrm{~N}^{\circ}$ and 122.1 to $122.6 \mathrm{E}^{\circ}$ ). Each datum point represents the average daily value. The red line represents the influenced periods of pre- and post-typhoon.

Vertical profiles of temperature $(T)$, salinity $(S)$, potential density ( $\sigma_{\theta}$, where $\theta$ is the potential temperature) in the study area after the typhoon (2 August 2008) are shown in Fig. 3ac, respectively. As it is difficult to obtain measured vertical hydrographic data in the field prior to a typhoon event because of the dangerous and unpredictable sea conditions of the typhoon, temperature-salinity-density $\left(T-S-\sigma_{\theta}\right)$ diagrams (Fig. 3d) during non-typhoon (in June and August 2007) and typhoon periods (August 2008) were used to demonstrate the vertical mixing vs. upwelling process in the study area. A typical $T-S-\sigma_{\theta}$ diagram is shown in Fig. 3d. The red curve shows source water of the Kuroshio subsurface upwelling in the SECS. During a non-typhoon period, weak upwelling resulting from subsurface water of the Kuroshio was detected in June (blue curve) and August (purple curve) 2007, respectively. Upwelled cold water consequently mixed with warm surface water of the SECS, resulting in slight changes in the $T-S-\sigma_{\theta}$ diagrams (Fig. 3d).Thus, variability in $T-S$ $\sigma_{\theta}$ association in our study area was not remarkable based on the many CTD hydrocasts (gray points in Fig. 3d) noted under non-typhoon conditions. As upwelling was weak, the concentration of $\mathrm{NO}_{3}$ in the surface layer was almost undetectable (e.g. $\sim 0 \mu \mathrm{M}$ ) (Fig. 3e) and the surface chl- $a$ concentrations (Fig. 3f) were $0.23 \mathrm{mg} \mathrm{m}^{-3}$ in June 2007 and
$0.41 \mathrm{mg} \mathrm{m}^{-3}$ in August 2007, respectively. However, it is evident that after passage of typhoon Fengwong (August 2008), colder nutrient-rich water (green curve in Figs. 3d and e) was brought to the surface from a deep water source derived from the Kuroshio upwelling, and this water mixed with surface water of the SECS resulting in a high surface chl- $a$ value $\left(1.4 \mathrm{mg} \mathrm{m}^{-3}\right.$, Fig. 3f). In contrast, the source of cold water 5 days after typhoon Fengwong was significantly deeper than that under non-typhoon conditions (Fig. 3d).

P6, Table 1, line 12 should read C fluxa (mg C m-2 d-1): measured by sediment traps. Line 13 should read $C$ fluxb (mg $\mathrm{C}$ m-2 d-1): measured by sediment traps. Line 14 should read I-PP (mg C m-2 d-1): estimated.

When non-typhoon conditions were prevalent (June and August 2007), the depths of the euphotic zone were 65 and $43 \mathrm{~m}$ (Table 1), respectively. However, after the Fengwong and Sinlaku typhoon events, the euphotic zones became shallower (34 m and 30-32 m, respectively, Table 1) and the depth was only about half that of the mean euphotic zone depth reported by Gong et al. (2001) for this region $(60 \pm 10 \mathrm{~m})$. Fig. 4 shows the MODIS-derived average surface chl- $a$ concentrations before and after typhoons Fengwong and Sinlaku. The derived MODIS chl- $a$ values were much higher after typhoon Fengwong than before the typhoon (Fig. 4a and b), but the difference between derived chl- $a$ values pre-typhoon and post typhoon Sinlaku was less (Fig. 4c and d). MODIS-derived surface chl- $a$ values in the study area $\left(25.40^{\circ} \mathrm{N}, 122.45^{\circ} \mathrm{E}\right)$ were $0.77 \mathrm{mg} \mathrm{m}^{-3}$ (24-26 July), $0.93 \mathrm{mg} \mathrm{m}^{-3}$ (31 July-2 August), $0.30 \mathrm{mg} \mathrm{m}^{-3}$ (8-10 September) and $0.70 \mathrm{mg} \mathrm{m}^{-3}$ (17-19 September), respectively. In comparison, the field-measured chl- $a$ value $\left(1.4 \mathrm{mg} \mathrm{m}^{-3}\right.$ ) at $2 \mathrm{~m}$ on 2 August (after typhoon Fengwong) was $50 \%$ higher than the derived 3-day average chl- $a$ value $\left(0.93 \mathrm{mg} \mathrm{m}^{-3}\right)$ determined using MODIS. In situ surface chl$a$ concentrations on 19 and 21 September were 1.01 and $0.56 \mathrm{mg} \mathrm{m}^{-3}$, respectively. Similarly, the in situ chl- $a$ value $\left(1.01 \mathrm{mg} \mathrm{m}^{-3}\right)$ on 19 September was also higher than the derived 3-day mean chl- $a$ value $\left(0.70 \mathrm{mg} \mathrm{m}^{-3}, 17-19\right.$ September) noted after passage of typhoon Sinlaku. It is noted that the unrealistically high chl- $a$ concentration obtained across the Taiwan Strait (Fig. 4b) might be caused by the strong absorption of colored dissolved organic matter (Gong, 2004; Gong et al., 2007; Tang et al., 2008).

\subsection{POC flux and vertical hydrographic values after passage of Fengwong and Sinlaku}

Diel variations of POC flux were measured in the ECS in March/April of 2008 (Hung et al., 2009, unpublished data). Daytime (8 a.m. to 5 p.m.) POC fluxes at $120 \mathrm{~m}$ and $150 \mathrm{~m}$ were $45.9 \pm 6.9 \mathrm{mg} \mathrm{C} \mathrm{m}^{-2} \mathrm{~d}^{-1}$ and $47.6 \pm 7.6 \mathrm{mg} \mathrm{C} \mathrm{m}^{-2} \mathrm{~d}^{-1}$, respectively. Nighttime (12 a.m. to 9 a.m.) POC fluxes at the same depths were $53.3 \pm 8.5 \mathrm{mg} \mathrm{C} \mathrm{m}^{-2} \mathrm{~d}^{-1}$ and $43.8 \pm$ $7.4 \mathrm{mg} \mathrm{C} \mathrm{m}^{-2} \mathrm{~d}^{-1}$, respectively. Li (2009) investigated POC fluxes using a time-series $(4,8,12$ and $24 \mathrm{~h})$ of trap 

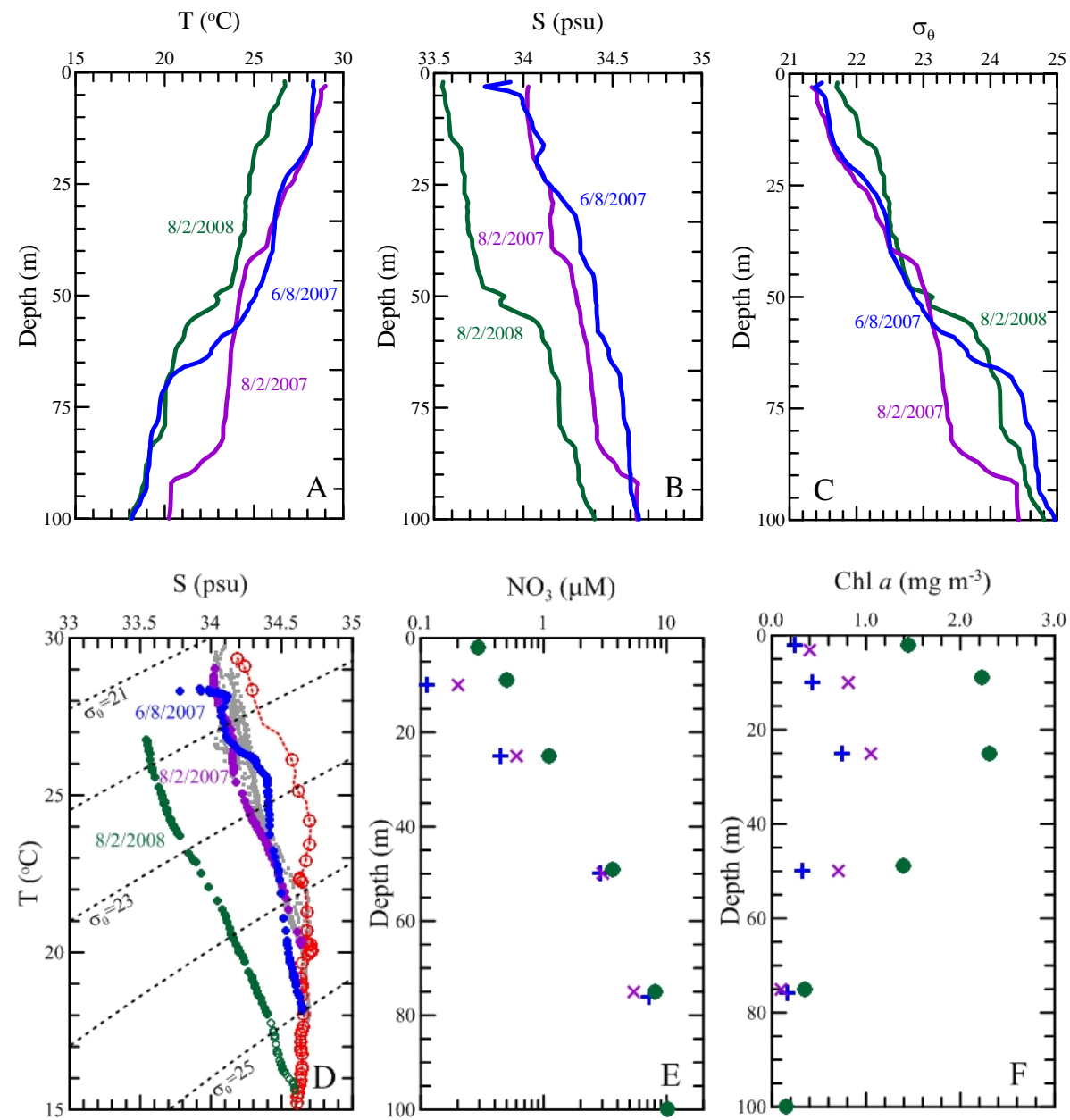

Fig. 3. Vertical profiles of temperature- $T(\mathbf{A})$, salinity- $S(\mathbf{B})$, density- $\sigma_{\theta}(\mathbf{C})$ in the study area of the southern East China Sea during nontyphoon periods (blue and purple curves) and after a typhoon event (green curve). Diagrams of $T-S$ - $\sigma_{\theta}$ (D): a red curve represents the characteristics of the Kuroshio Current; a green curve represents the nature of the upwelled water from the deeper water of the Kuroshio upwelling after a typhoon event; blue, purple, and gray curves represent the upwelled water from the shallow water of the Kuroshio Current under non-typhoon periods;). One can clearly see the colder water from deep water (after typhoon event was brought to the surface deeper than non-typhoon periods. Vertical distributions of nitrate concentration (E) and chlorophyll- $a$ (chl- $a$ ) concentration (F) in the study area of the southern East China Sea during non-typhoon periods (blue, purple, and gray symbols) and after a typhoon event (green symbols). Note: nitrate concentrations (below detection limit, $\sim 0 \mu \mathrm{M}$ ) in the surface water during non-typhoon periods did not appear because of log scale.

deployments in the same region of the present study and found no significant difference in POC flux between night and day. Thus, if diurnal variability in POC flux occurs, this may be small compared to other possible sources of error in our measurements. The trapping efficiency of floating sediment traps was $75 \%$ in the outer shelf of the East China Sea (Li, 2009) and $80 \%$ in the oligotrophic water of the northwest Pacific Ocean (Hung and Gong, 2007), based on the ${ }^{234} \mathrm{Th} /{ }^{238} \mathrm{U}$ disequilibrium model of Wei and Hung (1998) and Hung et al. (2010).

The vertical distribution of temperature, $\mathrm{NO}_{3}$ and chl- $a$ concentrations in the study area after the typhoon ( $2 \mathrm{Au}-$ gust 2008) are shown in Fig. 3. The temperature in the euphotic zone following the typhoon was significantly lower than that recorded during June and August, 2007 (Fig. 3a). The presence of colder water in the upper $\sim 70 \mathrm{~m}$ indicates that cooling was quite intense. When averaged over the upper $75 \mathrm{~m}$ of the water column (Table 1), the increase in $\mathrm{NO}_{3}$ concentration associated with this upwelling was $6.41 \mu \mathrm{M}\left(=0.534-(0.046+0.060) / 2 \mathrm{~mol} \mathrm{~m}^{-2}\right) / 75 \mathrm{~m}=$ $0.0064 \mathrm{~mol} \mathrm{~m}^{-3}$ ). The level of nitrogen associated with the increase in POC concentration must be added to this figure. The change in POC concentration (Table 1) was $2.39 \mu \mathrm{M}$ POC $\left.\left(=5.5-(3.5+3.2) / 2 \mathrm{~g} \mathrm{~m}^{-2}\right) / 75 \mathrm{~m}=0.02867 \mathrm{gC} \mathrm{m}^{-3}\right)$. Assuming that Redfield stoichiometry was relevant (Redfield, et al., 1963), such a change in POC concentration would be associated with an increase of $0.36(=2.39 / 6.625)$ $\mu \mathrm{M}$ in nitrogen. Thus the net increase in $\mathrm{N}$ in the upper $75 \mathrm{~m}$ 
Table 1. Data of mixed layer depth (MLD), euphotic zone (EZ: $1 \%$ of surface light intensity), integrated nitrate (I-NO ${ }_{3}$ ), chl- $a$ (IB), POC (I-POC) and POC flux from different cruises.

\begin{tabular}{lllllllllll}
\hline Date & $\begin{array}{l}\text { MLD } \\
(\mathrm{m})\end{array}$ & $\begin{array}{l}\mathrm{EZ} \\
(\mathrm{m})\end{array}$ & $\begin{array}{l}\mathrm{I}^{-\mathrm{NO}_{3}} \\
\mathrm{~mol} \mathrm{~m}^{-2}\end{array}$ & $\begin{array}{l}\mathrm{IB} \\
\mathrm{g} \mathrm{m}^{-2}\end{array}$ & $\begin{array}{l}\mathrm{I}-\mathrm{POC} \\
\mathrm{g} \mathrm{m}^{-2}\end{array}$ & $\begin{array}{l}\mathrm{C} \mathrm{flux}^{\mathrm{a}} \\
\text { (trap) }\end{array}$ & $\begin{array}{l}\mathrm{C} \mathrm{flux}^{\mathrm{b}} \\
\text { (model) }\end{array}$ & $\begin{array}{l}\mathrm{I}-\mathrm{PP} \\
\text { (model) }\end{array}$ & $\begin{array}{l}\mathrm{e}^{\mathrm{a}} \\
\text { (trap) }\end{array}$ & $\begin{array}{l}\mathrm{e}^{\mathrm{b}} \\
\text { (model) }\end{array}$ \\
\hline $6 / 10 / 2007$ & 34 & 65 & 0.046 & 0.031 & 3.2 & $180 \pm 10$ & 183 & 1111 & $0.16 \pm 0.01$ & 0.16 \\
$8 / 3 / 2007$ & 28 & 43 & 0.060 & 0.051 & 3.5 & $140 \pm 22$ & 219 & $1283 / 1773^{*}$ & $0.11 \pm 0.02$ & 0.17 \\
$8 / 3 / 2008$ & 45 & 34 & 0.534 & 0.116 & 5.5 & $265 \pm 14$ & 567 & 2775 & $0.10 \pm 0.01$ & 0.20 \\
$9 / 19 / 2008$ & n.a & 32 & n.a & n.a & n.a & $225 \pm 34$ & 277 & 1384 & $0.16 \pm 0.03$ & 0.20 \\
$9 / 21 / 2008$ & n.a & 30 & n.a & n.a & n.a & $224 \pm 33$ & 359 & 1711 & $0.13 \pm 0.04$ & 0.21 \\
\hline
\end{tabular}

MLD: defined at depth which density increased by $0.1 \mathrm{~kg} \mathrm{~m}^{-3}$ from the density at surface (Son et al., 2007)

$\mathrm{NO}_{3}$, IB, I-POC: integrated $\mathrm{NO}_{3}$, chl- $a$, POC from 0 to $75 \mathrm{~m}$

$\mathrm{C}$ flux ${ }^{\mathrm{a}}\left(\mathrm{mg} \mathrm{C} \mathrm{m}^{-2} \mathrm{~d}^{-1}\right)$ : measured by sediment traps.

$\mathrm{C}$ flux ${ }^{\mathrm{b}}\left(\mathrm{mg} \mathrm{C} \mathrm{m}^{-2} \mathrm{~d}^{-1}\right)$ : measured by sediment traps.

I-PP $\left(\mathrm{mg} \mathrm{Cm}^{-2} \mathrm{~d}^{-1}\right)$ : estimated by the model (of Behrenfeld and Falkowski, 1997).

$\mathrm{e}^{\mathrm{a}}$ : C flux ${ }^{\mathrm{a}} / \mathrm{I}-\mathrm{PP} ; \mathrm{e}^{\mathrm{b}}: \mathrm{C}$ flux ${ }^{\mathrm{b}} / \mathrm{I}-\mathrm{PP}$.

n.a.: data not available.

* PP value was measured by $\mathrm{C}-14$ incubation.

Data in 2007 from non-typhoon periods. Data in 2008 from post-typhoon periods.

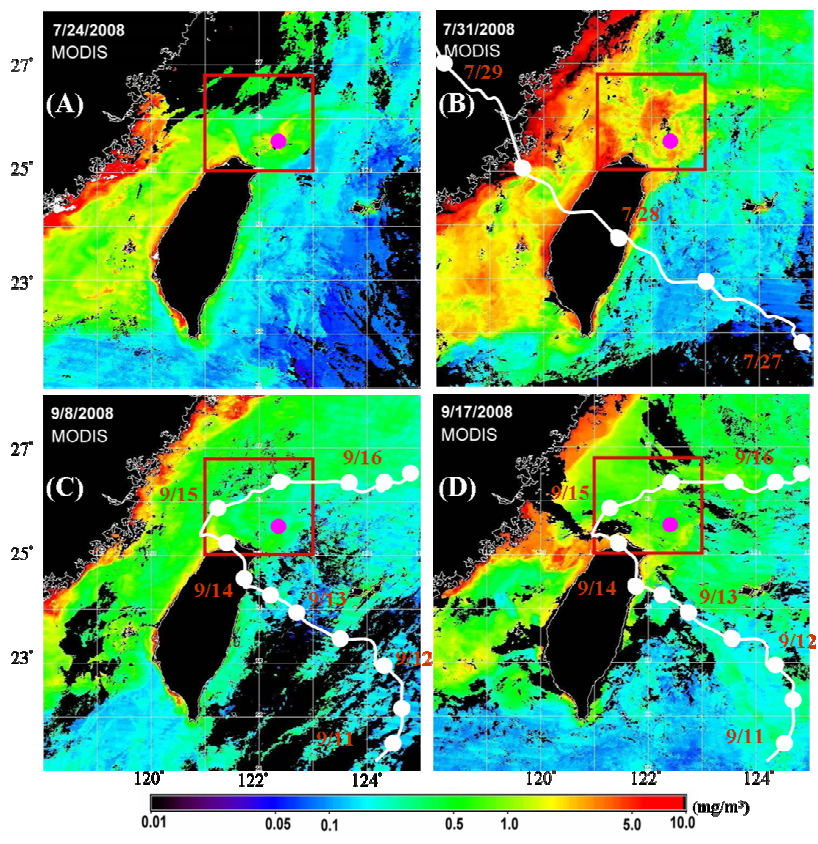

Fig. 4. The derived surface chl- $a$ concentrations by MODIS before and after typhoon Fengwong (panels $\mathbf{A}$ and $\mathbf{B}$, from 24 July to 31 July 2008) and Sinlaku (panels $\mathbf{C}$ and $\mathbf{D}$, from 8 September to 17 September 2008) respectively. A pink dot represents the sampling location and a white line represents the track of typhoons Fengwong and Sinlaku.

of the water column averaged $6.77(=6.41+0.36) \mu \mathrm{M}$.

Areal chl- $a$ (integrated chl- $a$ from 0 to $75 \mathrm{~m}$ ) concentration peaked on 3 August 2008 (at $116 \mathrm{mg} \mathrm{m}^{-2}$ ) and subsequently declined to $48 \mathrm{mg} \mathrm{m}^{-2}$ on 13 August 2008 . This was similar to the average maximum integrated chl- $a$ concentration of $46 \mathrm{mg} \mathrm{m}^{-2}$ derived from extensive observa- tions in a similar study region $\left(25.5^{\circ} \mathrm{N}, 122.17^{\circ} \mathrm{E}\right)$ in good weather conditions (Gong, et al., 2000, 2001). The change in areal chl- $a$ concentration associated with typhoon Fengwong was therefore $72 \mathrm{mg} \mathrm{m}^{-2}(=116-(31+51+48+46) / 4)$ and the associated change in areal POC (integrated POC from 0 to $75 \mathrm{~m})$ level was $2.15(=5.5-(3.5+3.2) / 2) \mathrm{g} \mathrm{m}^{-2}$, giving a $\Delta \mathrm{POC} / \Delta \mathrm{chl}-a$ ratio of $30 \mathrm{gC} \mathrm{g}^{-1} \mathrm{chl}-a(=2.15 / 0.072)$. This is similar to the geometric mean $\left(36 \mathrm{gC} \mathrm{g}^{-1}\right.$ chl- $\left.a\right)$ of the range of carbon/chl- $a$ ratios reported for phytoplankton from eutrophic environments by Riemann et al. (1989), suggesting that most of the increase in POC following typhoon Fengwong was associated with an increase in phytoplankton biomass. Most previous studies using satellite surface color images suitable for large scale observations have focused on the surface layer, and hydrographic variation at depth has seldom been observed.

The POC flux at $70 \mathrm{~m}$ was approximately $265 \pm$ $14 \mathrm{mg} \mathrm{C} \mathrm{m}^{-2} \mathrm{~d}^{-1} 5$ days after the passage of typhoon Fengwong (Table 1). As we were unable to directly measure the effect of typhoon Fengwong on POC flux, we compared post-typhoon POC flux with fluxes measured during nontyphoon conditions in June and August 2007, which were $180 \pm 10$ and $140 \pm 22 \mathrm{mg} \mathrm{C} \mathrm{m}^{-2} \mathrm{~d}^{-1}$, respectively (Table 1 and Fig. 5). The elevated post-typhoon POC export flux is unlikely to have been caused by lateral transport of coastal waters or riverine input because the transmissometer profiles did not show any anomalies, and satellite color images did not display any unusual terrestrial influence due to a significant gap between Chinese coast and the study area (Fig. 4). Enhanced POC export in the SECS was also observed after passage of typhoon Sinlaku in September 2008. Measured POC fluxes in the SECS study area 5 and 7 days after passage of this typhoon were $225 \pm 34$ and $224 \pm 33 \mathrm{mg} \mathrm{C} \mathrm{m}^{-2} \mathrm{~d}^{-1}$, respectively (Table 1). 


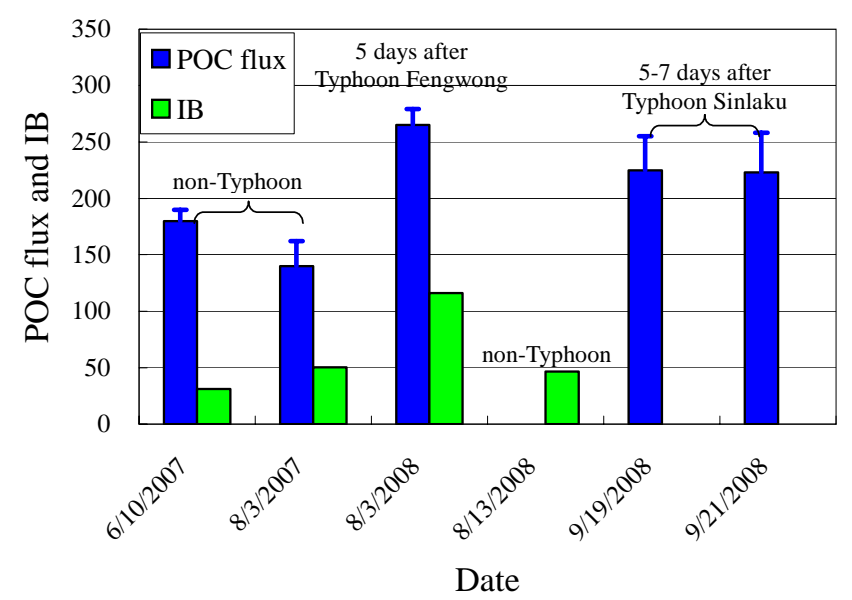

Fig. 5. POC export fluxes (blue bars, $\mathrm{mg} \mathrm{C} \mathrm{m}^{-2} \mathrm{~d}^{-1}$ ) and integrated chl- $a$ (IB, green bars: $\mathrm{mg} \mathrm{m}^{-2}$ ) in the study region on $6 / 10$ in 2007 , $8 / 3$ in 2007 , and $8 / 13$ in 2008 (non-typhoon conditions), and during typhoon events in 2008 on 8/3 (typhoon Fengwong), and 9/19 and 9/21 in 2008 (typhoon Sinlaku).

The change in areal POC concentration following typhoon Fengwong $\left(2.15 \mathrm{~g} \mathrm{C} \mathrm{m}^{-2}\right)$ can be equated to the difference between the integrals of new production and export production following the typhoon. Assuming that export production increased linearly from a baseline of $160(=(180+140) / 2) \mathrm{mg} \mathrm{C} \mathrm{m}^{-2} \mathrm{~d}^{-1}$ to $265 \pm$ $14 \mathrm{mg} \mathrm{m}^{-2} \mathrm{~d}^{-1}$ five days later, the integral of export production during that time interval is $1.06 \mathrm{gC} \mathrm{m}^{-2}$ $\left(=(160+265) \times(5 / 2)=1062.5 \mathrm{mg} \mathrm{C} \mathrm{m}^{-2}\right)$. Addition of this value to the observed increase in POC yields $3.21(=5.5-(3.2+3.5) / 2+1.06) \mathrm{gC} \mathrm{m}^{-2}$ for the integral of new production, i.e., a new production rate of 0.642 $(=3.21 / 5) \mathrm{gC} \mathrm{m}^{-2} \mathrm{~d}^{-1}$ following the typhoon.

\section{Discussion}

\subsection{Hydrographic settings during non-typhoon and post-typhoon periods}

Dramatic effects of typhoons on chl- $a$ levels, biological variables, and phytoplankton production have been reported several days following the passage of typhoons based on data from satellite color images or field experiments (Babin, et al., 2004; Chang, et al., 2008; Lin, et al., 2003; Shiah, et al., 2000; Walker, et al., 2005; Siswanto et al., 2007; Zhao, et al., 2008; Zheng and Tang, 2007). The satellite-derived SST data used in the present study clearly showed cooling after the passage of typhoons Fengwong and Sinlaku (Figs. 2a and b). Many previous reports have focused on variation in SST (e.g. entrainment of cold, nutrient-rich water brought to the surface), surface ocean color images, and sea level anomalies between pre- and post-typhoon periods (Chang, et al., 2008; Lin, et al., 2003; Zheng and Tang, 2007). Figure 2b

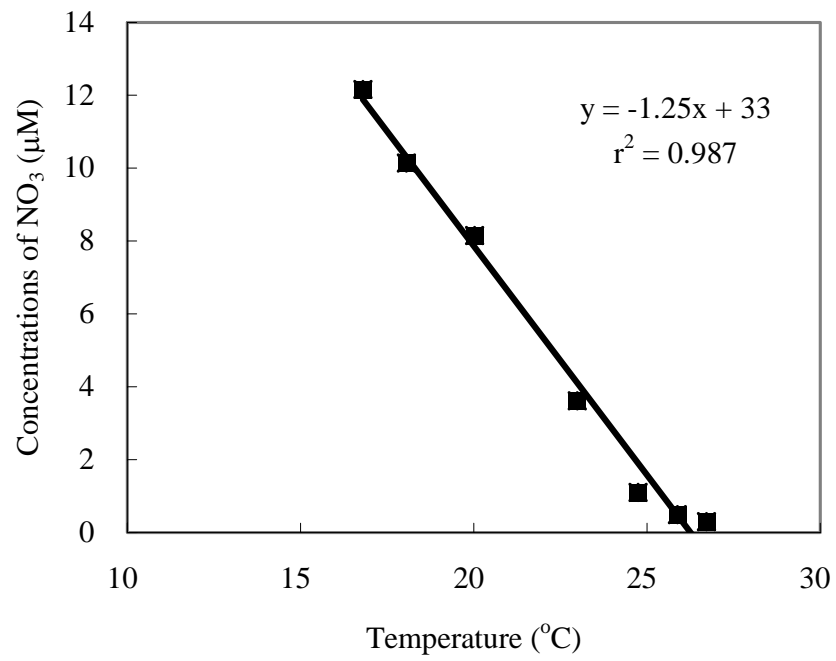

Fig. 6. Relationship between and sea surface temperature (SST) and nitrate concentration in the study area of the southern East China Sea.

shows how SST in the area of the cold water patch changed over time following passage of typhoon Fengwong, with the lowest SST evident in the cooling core. This demonstrates that satellite-derived information can be used to complement in situ sampling for assessment of the impact of cooling on POC production and flux (see discussion in Sect. 4.3). Figure 6 shows a strong relationship between $\mathrm{SST}$ and $\mathrm{NO}_{3}$ concentration in the study area. The decline in SST caused by typhoons could be caused by various processes including evaporative heat loss, wind enhanced vertical mixing, wind induced upwelling, and a reduction in solar insolation because of increased cloud cover, but delineation of the extent of involvement, and the contributions of different processes to observed cooling (e.g. SST change), is exceedingly complicated. The SST cooling factors are complicated, but they can be use to predict the nitrate concentration from the SST data after a typhoon if the relationship between temperature and nitrate in the open ocean is known. This is important when using an algorithm to estimate new production (NP) by means of remotely sensed ocean color to determine the nitrate concentration in the euphotic zone (e.g., Dugdale et al., 1989; Sathyendranath et al., 1991).

Chl $-a$ concentrations $\left(\sim 0.24 \mathrm{mg} \mathrm{m}^{-3}\right.$ in June 2007 and $0.41 \mathrm{mg} \mathrm{m}^{-3}$ in August 2007) at $5 \mathrm{~m}$ changed to $1.4 \mathrm{mg} \mathrm{m}^{-3}$ on 2 August 2008 (Fig. 3f), associated with the presence of cold nutrient-rich water. A linear plot of chl- $a$ concentration versus the visible light attenuation coefficient $(=\ln (100) / \mathrm{EZ}$ from Table 1, EZ: euphotic zone), gives a slope of $37 \mathrm{~m}^{2} \mathrm{~g}^{-1}$ chl- $a$ (Fig. 7, $r^{2}=0.976$ ), suggesting that virtually all of the decrease in EZ following typhoon Fengwong can be explained by a rise in phytoplankton biomass within the euphotic zone. The slope is in agreement with the previously reported values $\left(30 \mathrm{~m}^{2} \mathrm{~g}^{-1} \mathrm{chl}-a\right.$ at an irradiance equal 


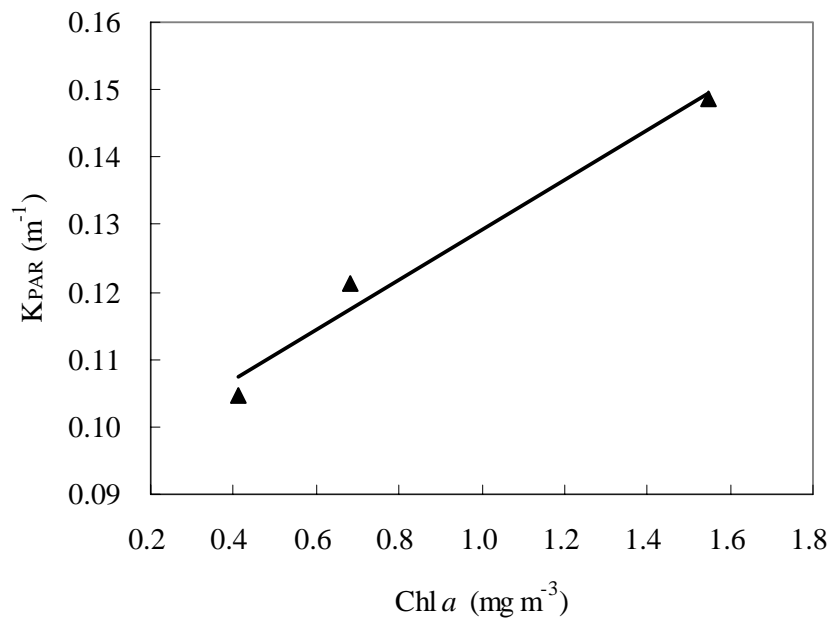

Fig. 7. A relationship between chl- $a$ concentration versus vertical light attenuation coefficient $\left(K_{\mathrm{PAR}}\right)$.

to $33 \%$ of the surface level and $\sim 40 \mathrm{~m}^{2} \mathrm{~g}^{-1}$ chl- $a$ at greater depths) (Laws et al., 1990).

It is noteworthy that in situ concentrations of chl- $a$ (1.4 and $1.0 \mathrm{mg} \mathrm{m}^{-3}$ on 2 August and 19 September, respectively) were higher than satellite derived average chl- $a$ values $(0.9$ and $0.7 \mathrm{mg} \mathrm{m}^{-3}$ on 2 August and 17-19 September, respectively), suggesting that the derived chl- $a$ values might be underestimated by use of satellite color images following a typhoon. Although we recognize that the data are limited, we would suggest several possible explanations. (1) Just after the passage of the typhoon the concentration of surface chl$a$ is likely to decrease, because chl- $a$ is mixed from surface waters to greater depth. Shortly after the typhoon the chl- $a$ is expected to increase in response to higher nutrient concentrations and increasing water stability. After some more time the chl- $a$ concentration is like to decrease again when nutrient are used up and their concentrations are decreasing. The measured chl- $a$ concentration was obtained at a specific location several days post-typhoon during a time of rapid phytoplankton growth, whereas the derived chl- $a$ value was a 3-day mean value derived from a large area $\left(1 \times 1 \mathrm{~km}^{2}\right)$ and including periods of both high and low phytoplankton growth; (2) The phytoplankton community may change after a typhoon (see detailed discussion in Sect. 4.3); (3) Sampling time differences between the two approaches could be influential if phytoplankton show diel variation in compositional characteristics. However, the presence of suspended particles and/or chromophoric dissolved organic matter (CDOM) may cause satellite-derived chl- $a$ measurements to overestimate in situ concentrations (Hoge and Lyon, 2002; Tang et al., 2008; Shang et al., 2008). Therefore, further evaluation of the relationship between in situ chl- $a$ and satellite derived chl- $a$ is warranted.

One obvious benefit of in situ sampling following typhoons is acquisition of information on vertical variation in nutrient concentration and phytoplankton biomass. Figure $3 \mathrm{~b}$ and $\mathrm{C}$ show the vertical profiles of $\mathrm{NO}_{3}$ and chl- $a$ concentrations after the passage of typhoon Fengwong. When the chl- $a$ concentrations are converted to phytoplankton nitrogen assuming a carbon/chl- $a$ ratio of 30 (see above) and the Redfield C/N (Redfield, et al., 1963), it becomes apparent that phytoplankton uptake five days after the typhoon had removed only $5.3 \%$ of $\mathrm{NO}_{3}(=0.36 / 6.77)$ in the upper $75 \mathrm{~m}$ of the water column. Why was so little upwelled $\mathrm{NO}_{3}$ assimilated by phytoplankton? With an initial areal chl- $a$ concentration of $\sim 0.041 \mathrm{~g} \mathrm{~m}^{-2}(=(0.051+0.041) / 2)$ (Table 1), and assuming a carbon/chl- $a$ ratio of 30 (see above), the biomass of phytoplankton just prior to typhoon Fengwong would have been $1.23 \mathrm{~g} \mathrm{C} \mathrm{m}^{-2}$ or approximately $37 \%\left(=1.23 \mathrm{~g} \mathrm{C} \mathrm{m}^{-2} / 3.35 \mathrm{~g} \mathrm{C} \mathrm{m}^{-2}\right)$ of the POC in the water column. Areal chl- $a$ concentration roses from about 44 to $116 \mathrm{mg} \mathrm{m}^{-2}$, thus showing a net rate of increase of approximately $0.19 \mathrm{~d}^{-1}(=(\ln 116-\ln 44) / 5$ day $)$ or a doubling time of $3.6(=(\ln 2) / 0.19)$ days. Assuming approximately one doubling each 3.6 days, phytoplankton biomass in the upper $75 \mathrm{~m}$ of the water column could have increased to $3.2 \mathrm{gC} \mathrm{m}^{-2}$ in five days, only equivalent to $0.53 \mu \mathrm{M}$ $\left(=3.2 \mathrm{gC} \mathrm{m}^{-2} / 12 \mathrm{~g} \mathrm{~mol}^{-1} / 75 \mathrm{~m} / 6.6\right)$ phytoplankton nitrogen, thus significantly lower than the observed $\mathrm{NO}_{3}$ pumping $(6.77 \mu \mathrm{M})$. As these calculations are based on integration to a depth of $75 \mathrm{~m}$, and because the $1 \%$ light level was substantially shallower than $75 \mathrm{~m}(31-44 \mathrm{~m})$, the slow growth rate was probably attributable in part to considerable light limitation. An additional explanation for failure of the phytoplankton population to increase is grazing by protozoa, which are able to multiply rapidly and are among the dominant herbivores in tropical and subtropical open ocean food chains (Laws, et al., 2000).

\subsection{POC fluxes following the passage of typhoons Fengwong and Sinlaku}

Although typhoon Sinlaku was a category 3 typhoon, the lowest SST $\left(26.5^{\circ} \mathrm{C}\right)$ in the SECS caused by this typhoon was higher than that $\left(25.7^{\circ} \mathrm{C}\right)$ resulting from passage of typhoon Fengwong. Overall, the impact of both typhoons on SST levels in the SECS was similar to the effect of the category 5 typhoon Haitang, which passed over Taiwan on 18 19 July 2005 (Chang, et al., 2008; Tsai et al., 2008). On 22 July 2005, after the passage of typhoon Haitang, the cooling area $\left(<26^{\circ} \mathrm{C}\right)$ expanded rapidly to occupy a crescent shaped region of $9146 \mathrm{~km}^{2}$. This increased area of cooling weakened gradually but persisted for more than 1 week. Additionally, Zheng and Tang (2007) found an initial decrease in SST $\left(0.5-2^{\circ} \mathrm{C}\right)$ associated with the passage of a typhoon in the South China Sea, whereas a large decrease in SST (4$5^{\circ} \mathrm{C}$ ) was noted 1 day after passage.

The measured POC fluxes in the SECS 5 and 7 days after passage of typhoon Sinlaku were $225 \pm 34$ and $224 \pm$ $33 \mathrm{mg} \mathrm{C} \mathrm{m}^{-2} \mathrm{~d}^{-1}$, respectively. These values are higher than 
the fluxes seen in June and August 2007, but less than the flux observed following the passage of typhoon Fengwong (265 \pm $\left.14 \mathrm{mg} \mathrm{m}^{-2} \mathrm{~d}^{-1}\right)$. As the sustained wind speeds $\left(51 \mathrm{~m} \mathrm{~s}^{-1}\right)$ during typhoon Sinlaku were significantly higher than those during typhoon Fengwong $\left(43 \mathrm{~m} \mathrm{~s}^{-1}\right)$, it is reasonable to assume that more nutrients were injected into the upper water column upon passage of the former typhoon. Other factors being equal, one might anticipate that POC fluxes would be greater 5-7 days after typhoon Sinlaku. Why was this evidently not the case?

As noted above, the amount of $\mathrm{NO}_{3}$ injected into the upper $75 \mathrm{~m}$ of the water column after typhoon Fengwong had the potential to cause a much greater bloom of phytoplankton than was observed. The increase in phytoplankton biomass after a typhoon clearly depends on much more than physics. The greater level of wind mixing associated with typhoon Sinlaku likely increased the depth of the mixed layer (MLD) to an extent greater than that associated with typhoon Fengwong. It is apparent from Table 1 and Fig. 3 that the MLD $(45 \mathrm{~m})$ after passage of typhoon Fengwong was deeper than the euphotic zone $(34 \mathrm{~m})$. Further deepening of the mixed layer would reduce the areal concentration of phytoplankton in the euphotic zone and hence reduce net community production (Sverdrup, 1953) because chl- $a$ concentrations declined rapidly at depths below $45 \mathrm{~m}$ (Fig. 3f). Since the $\mathrm{NO}_{3}$ concentrations at most depths in the water column following typhoon Fengwong were more than adequate to saturate phytoplankton uptake kinetics (Eppley, et al., 1969), there is no reason to believe that additional mixing would have increased growth rates. Indeed, additional mixing and deepening of the mixed layer would have reduced growth rates due to light limitation. This scenario very likely explains the lower rates of POC export following typhoon Sinlaku, compared to those noted following the passage of typhoon Fengwong.

Other factors are worthy of consideration. Based on the recorded track (Figs. 4c and d), the center of typhoon Fengwong did not pass directly through the study area. Previous reports have indicated that upwelling and sea surface cooling are primarily observed along the typhoon track, or to the right of the typhoon center, suggesting that wind-enhanced eddy pumping and/or vertical mixing are major mechanisms involved in these phenomena (Lin, et al., 2003; Shang, et al., 2008; Walker, et al., 2005; Zheng and Tang, 2007). For example, enhanced phytoplankton growth to the right of a typhoon track has been reported in the Gulf of Mexico (Walker, et al., 2005) and the South China Sea (Zheng and Tang, 2007). The study area was close to the storm center of typhoon Sinlaku but to the right of the track of typhoon Fengwong. Moreover, the two typhoons Fengwong and Sinlaku had dissimilar paths (Fig. 4b-d). Typhoon Sinlaku after crossing Taiwan (13-14 September) veered to the northeast over the study area. Tsai et al. (2008) reported that SST in the SECS changed abruptly when typhoons passed by Taiwan from the east or the west, and the complicated flow field off northeastern Taiwan could be dramatically altered by typhoons. The observed fast cooling after typhoon Sinlaku might be due to the upwelling of the Kuroshio subsurface water, then accompanied by Kuroshio surface water intrusion onto the continental shelf. Other factors such as Kuroshio instability, internal tide, impinging meso-scale eddies, etc, may also affect the flow field off SECS (Tsai et al., 2008). A better understanding of the relative importance of upwelling and mixing in the SECS will require more field observations. Furthermore, photosynthetic rates are probably limited by light (controlled by cloud cover) and the size of the phytoplankton population after passage of typhoons. Typhoon Sinlaku occurred approximately 7 weeks after typhoon Fengwong, and it appears that daily insolation was about $13 \%$ lower during the latter typhoon (http: //aom.giss.nasa.gov/srlocat.html).

\subsection{Implications for new and export production after typhoon events}

Boyd and Trull (2007) pointed out that many recent biogeochemical models may over-estimate global POC export flux and suggested that for global carbon modeling, more field observations were needed to validate modeled estimates (Laws, et al., 2000; Moore, et al., 2002). Many typhoons and hurricanes occurring in tropical open oceans each year (Webster, et al., 2005), and their collective effects on carbon export flux remain unclear because of sampling difficulties. We used existing algorithms to estimate primary production (PP) (Behrenfeld and Falkowski, 1997) and new and export production (Laws, et al., 2000). The algorithm of Laws et al. (2000) is a steady state model in which new and export production are assumed to be the same. The estimated new/export production in the present study was $183-219 \mathrm{mg} \mathrm{C} \mathrm{m}^{-2}$ day $^{-1}$ during June and August 2007, $567 \mathrm{mg} \mathrm{C} \mathrm{m}^{-2} \mathrm{day}^{-1}$ following typhoon Fengwong, and 277-359 $\mathrm{mg} \mathrm{C} \mathrm{m}^{-2}$ day $^{-1}$ after typhoon Sinlaku. The modeled new/export production during June/August 2007 was slightly higher than the measured POC flux (Table 1). A likely explanation for this discrepancy is that some of carbon export from the open ocean at such latitudes is attributable to convective mixing of dissolved organic carbon (Carlson, et al., 1994). Five days after typhoon Fengwong, the average of new/export production was $454(=642+265) / 2) \mathrm{mg} \mathrm{Cm}^{-2}$ $\mathrm{day}^{-1}$, which is lower than the modeled new/export production of $567 \mathrm{mg} \mathrm{C} \mathrm{m}^{-2} \mathrm{day}^{-1}$. At 5-7 days after typhoon Sinlaku, the modeled average new/export production was 318 $(=(277+359) / 2) \mathrm{mg} \mathrm{C} \mathrm{m}^{-2} \mathrm{day}^{-1}$. If this is likewise indicative of the average of new and export production at that time, the implied new production would be $412(=318 \times 2-$ 224) $\mathrm{mg} \mathrm{C} \mathrm{m}^{-2} \mathrm{day}^{-1}$, almost twice the measured POC export. This conclusion is roughly consistent with the behavior of new and export production five days following typhoon Fengwong, i.e., new production greater than POC export by a factor of 2.4 (= $\left.642 \mathrm{mg} \mathrm{C} \mathrm{m}^{-2} \mathrm{day}^{-1} / 265 \mathrm{mg} \mathrm{C} \mathrm{m}^{-2} \mathrm{day}^{-1}\right)$. 
Trap results (Table 1) suggest that the export ratio (POC flux/primary production) rises following typhoons. This probably reflects the fact that phytoplankton species composition changes from small-cell species to large diatoms due to the influence of nutrient-rich water. We did not investigate phytoplankton species composition in the present study, but we did examine phytoplankton assemblage changes (Hung et al., unpublished data) in the same study area between 520 August 2009, embracing the period before and after typhoon Morakot which passed over Taiwan on 8 August 2009. The major phytoplankton assemblages in surface waters before typhoon Morakot (5 August) were small dinoflagellates (cell size $<10 \mu \mathrm{m}$ ), including Gymnodinium spp. The abundance of Gymnodinium was about 1500 cells L $^{-1}$. Trichodesmium spp. were also found in the study area, implying that the surface waters were oligotrophic. However, the major phytoplankton assemblages 3 days (on 11 August) after typhoon Morakot were composed of pennate diatoms including Pseudonitzchia spp. and Nitzchia spp. Seven days (14 August) after passage of typhoon Morakot, the dominant phytoplankton species were large cell colony-formed diatoms including Chaetoceros, Thalassionema, and Skeletonema costatum. The highest abundance of these large diatoms (approximately $2 \times 10^{5}$ cells $\mathrm{L}^{-1}$ ) occurred ten days after the typhoon. Following the typhoon, phytoplankton abundance decreased dramatically. Nutrient conditions were similar in the study area before and after typhoons Fengwong and Morakot. Analogous phytoplankton species changes have been reported in the East China Sea (Chang et al., 1996) and the Kuroshio (Chen et al., 2009). During non-typhoon conditions, a substantial proportion of export production may be associated with convective mixing of DOC (Carlson, et al., 1994). The model of Laws et al. (2000) suggests that the export ratio after typhoon is higher than that during nontyphoon conditions (Table 1). If this is true, the implication is that an important difference between typhoon and nontyphoon conditions is the mechanism of export: primarily POC sinking following typhoons and roughly equal contributions from POC sinking and convective mixing of DOC during non-typhoon conditions.

\section{Conclusions}

This study involved direct measurement of POC flux in the southern East China Sea several days after each of two typhoons. The POC flux after a typhoon was greater than that during non-typhoon periods, indicating that biogenic carbon sinking induced by a typhoon is more efficient than that during non-typhoon conditions. The enhanced POC export flux noted following typhoon Fengwong was attributed to a phytoplankton bloom, as evidenced by a dramatic increase in areal chl- $a$ concentration. The failure of the phytoplankton community to assimilate more of the available nitrate may reflect the small initial size of the phytoplankton assemblages and the fact that the rate of increase in abundance of the phytoplankton community was constrained by a combination of light limitation and grazing.

POC export fluxes observed in the field were lower than those predicted by Laws et al. (2000) during non-typhoon conditions, probably because a substantial amount of the organic carbon export at such times is associated with convective mixing of DOC. Following typhoon Fengwong, there was excellent agreement between the model's estimate of new/export production and the average of estimated new production and POC export, suggesting that following typhoons most export occurs via sinking POC. Further studies are required to elucidate the mechanism of cooling after typhoons, and to quantify the contribution of storm events to global POC export flux in other marine environments including marginal seas and tropical open oceans. The field observations of this study were conducted within a small area because of poor weather conditions. The availability of numerous moorings may be useful to help clarify physical mixing mechanisms and to enable a comprehensive understanding of biological processes operative during and after typhoons.

Acknowledgements. We appreciate the assistance of the crew of the R/V Ocean Research II, G.-S. Hsieh, J.-M. Wu, and C. W. Tseng. The positive comments of three anonymous reviewers are also deeply appreciated. This research was supported by the National Research Council of Taiwan (NSC98-2628-M-019011, NSC99-2628-M-019-011, NSC98-2611-M-019-014-MY3, NSC99-2621-B-019-001-MY3) and the Center for Marine Bioenvironment and Biotechnology at the National Taiwan Ocean University.

Edited by: E. Boss

\section{References}

Atlas, D. A. and Bannister, T. T.: Dependence of mean spectral extinction coefficient of phytoplankton on depth, water color, and species, Limnol. Oceanogr., 25, 157-159, 1980.

Babin, S. M., Carton, J. A., and Dickey, T. D.: Satellite evidence of hurricane-induced phytoplankton blooms in an oceanic desert, J. Geophys. Res., 109, C03043, doi:10.1029/2003JC001938, 2004.

Bates, N. R., Knap, A. H., and Michaels, A. F.: The effect of hurricanes on the local to global air-sea exchange of $\mathrm{CO}_{2}$, Nature, 395, 58-61, 1998.

Behrenfeld, M. J. and Falkowski, P. G.: Photosynthetic rates derived from satellite-based chlorophyll concentration, Limnol. Oceanogr., 42, 1-20, 1997.

Boyd, P. W. and Trull, T. W.: Understanding the export of biogenic particles in ocean water: Is there consensus?, Progr. in Ocean., 72, 276-312, 2007.

Carlson, C. A., Ducklow, H. W., and Michaels, A. F.: Annual flux of dissolved organic carbon from the euphotic zone in the northwestern Sargasso Sea, Nature, 371, 405-408, 1994.

Chang, J., Chung, C.-C., and Gong, G.-C.: Influences of cyclones on chlorophyll- $a$ concentration and Synechococcus abundance in 
a subtropical western Pacific coastal ecosystem, Mar. Ecol. Prog. Ser., 140, 199-205, 1996.

Chang, Y.-L., Wu, C.-R., and Qey, L.-Y.: Bimodal behavior of the seasonal upwelling off the northeastern coast of Taiwan, J. Geophys. Res., 114, C03027, doi:10.1029/2008JC005131, 2009.

Chang, Y., Liao, H.-T., Lee, M.-A., Chan, J.-W., Shieh, W.-J., Lee, K.-T., Wang, G.-H., and Lan, Y.-C.: Multisatellite observation on upwelling after the passage of Typhoon Hai-Tang in the southern East China Sea, Geoph. Res. Lett., 35, L03612, doi:10.1029/2007GL032858, 2008.

Chen, C. T. A., Liu, C.-T., Chuang, W. S., Yang, Y. J., Shiah, F.-K., Tang, T. Y., and Chung, S. W.: Enhanced buoyancy and hence upwelling of subsurface Kuroshio waters after a typhoon in the southern East China Sea, J. Mar. Sys., 42, 65-79, 2003.

Chen, Y.-L. L., Chen, H.-Y., Jan, S., and Tuo, S.-H.: Phytoplankton productivity enhancement and assemblage change in the upstream Kuroshio after typhoons, Mar. Ecol. Prog. Ser., 385, 111 126, 2009.

Chern, C. S., Wang, J., and Wang, D. P.: The exchange of Kuroshio and East China Sea shelf water, J. Geophys. Res., 95, 1601716023, 1990.

Chuang, W.-S. and Liang, W.-D.: Seasonal variability of intrusion of the Kuroshio water across the continental shelf northeast of Taiwan, J. Ocean., 50, 531-542, 1994.

Dugdale, R. C., Morel, A., Bricaud, A., and Wilkerson, F. P.: Modeling new production in upwelling centers: a case study of modeling new production from remotely sensed temperature and color, J. Geophys. Res., 94, 18119-18131, 1989.

Emerson, S., Quay, P., Karl, D., Winn, C., Tupas, L., and Landry, M.: Experimental determination of the organic carbon flux from open-ocean surface waters, Nature, 389, 951-954, 1997.

Eppley, R. W., Rogers, J. N., and McCarthy, J. J.: Half-saturation constants for uptake of nitrate and ammonium by marine phytoplankton, 14, 912-920, 1969.

Gong, G.-C., Chang, J., and Liang, M.-H.: A photosyntheticirradiance model for the upwelling region northeast off Taiwan and its application to the East China Sea, J. Geophys. Res., 106, 19957-19968, 2001.

Gong, G.-C., Shiah, F.-K., Liu, K.-K., Chuang, W.-S., and Chang, J.: Effect of the Kuroshio intrusion on the chlorophyll distribution in the southern East China Sea north of Taiwan during spring, 1993, Contin. Shelf Res., 17, 79-94, 1997.

Gong, G.-C., Shiah, F.-K., Liu, K.-K., Wen, Y.-H., and Liang, M.H.: Spatial and temporal variation of chlorophyll- $a$, primary productivity and chemical hydrography in the southern East China Sea, Contin. Shelf Res., 20, 411-436, 2000.

Gong, G.-C., Liu, K. K., and Pai, S.-C.: Prediction of nitrate concentration from two end member mixing in the Southern East China Se, Contin. Shelf Res., 15, 827-842, 1995.

Gong, G.-C., Chang, J., and Wen, Y.-H.: Estimation of annual primary production in the Kuroshio waters northeast of Taiwan using a photosynthesis-irradiance model, Deep-Sea Res. Pt. I, 46, 93-108, 1999.

Gong, G.-C.: Absorption coefficients of colored dissolved organic matter in the surface waters of the East China Sea, Terr. Atmos. Ocean. Sci., 15, 1, 75-87, 2004.

Gong, G.-C., Hung, C.-C., and Chang, J.: Reply to comment by Jinchun Yuan et al. on "Reduction of primary production and changing of nutrient ratio in the East China Sea: effect of the Three Gorges Dam?", Geophys. Res. Lett., 34, L14610, doi:10.1029/2007GL029633, 2007.

Hoge, F. and Lyon, P. E.: Satellite observation of Chromophoric Dissolved Organic Matter (CDOM) variability in the wake of hurricanes and typhoons, Geophys. Res. Lett., 29(19), 141-144. 2002.

Hung, C.-C. and Gong G.-C.: Export flux of POC in the main stream of the Kuroshio, Geophys. Res. Lett., 34, L14610, doi:10.1029/2007GL029633, 2007.

Hung, C.-C., Gong, G.-C., Chung, W.-C., Kuo, W.-T., and Lin F.-C.: Enhancement of particulate organic carbon export flux induced by atmospheric forcing in the subtropical oligotrophic northwest Pacific Ocean, Mar. Chem., 113, 19-24, doi:10.1016/j.marchem.2008.11.004, 2009.

Hung, C.-C., Guo, L., Roberts, K., and Santschi, P. H.: Upper ocean carbon flux determined by ${ }^{234} \mathrm{Th}$ and sediment traps in the Gulf of Mexico, Geochem. J., 38, 601-611, 2004.

Hung, C.-C., Guo, L., Schultz, G., Pinckney, and Santschi, P. H.: Production and flux of carbohydrate species in the Gulf of Mexico, Global Biogeochem. Cy., 17, 2, 1055, doi:10.1029/2002GB001988, 2003.

Hung, C.-C., Xu, C., Santschi, P. H., Zhang, S.-J., Schwehr, K. A., Quigg, A., Guo, L., Gong, G.-C., Pinckney, J. L., Long, R. A., and Wei, C.-L.: Comparative evaluation of sediment trap and ${ }^{234}$ Th-derived POC fluxes from the upper oligotrophic waters of the Gulf of Mexico and the subtropical northwestern Pacific Ocean, Mar. Chem., 121, 132-144, doi:10.1016/j.marchem.2010.03.011, 2010.

Laws, E. A., DiTullio, G. R., Carder, K. L., Betzer, P. R., and Hawes, S.: Primary production in the deep blue sea, Deep-Sea Res. Pt. A., 37, 715-730, 1990.

Laws, E. A., Falkowski, P. G., Smith, W. O., Ducklow, H., and McCarthy, J. J.: Temperature effects on export production in the open ocean, Global Biogeochem. Cy., 14, 1231-1246, 2000.

Lee, M. A., Chang, Y., Sakaida, F., Kawamura, H., Chan, J. W., Cheng, C. H., and Huang, I.: Validation of the satellite-derived SSTs in the waters around Taiwan, Terr. Atmos. Ocean. Sc., 16, 1189-1204, 2005.

Li, S.-L.: Particulate organic carbon flux in the upwelling region off northeastern Taiwan, Thesis, National Taiwan Ocean University, Keelung, Taiwan, 2009.

Lin, I.-I., Liu, W. T., Wu, C.-C., Wong, G. T. F., Hu, C., Chen, Z., Liang, W.-D., Yang, Y., and Liu, K. K.: New evidence for enhanced ocean primary production triggered by tropical cyclone, Geophys. Res. Lett., 30, 13, 1718, doi:10.1029/2003GL017141, 2003.

Liu, K. K., Gong, G.-C., Lin, S., Yang, C.-Y., Wei, C.-L., Pai, S.-C., Wu, C.-K.: The year-round upwelling at the shelf break near the northern tip of Taiwan as evidenced by chemical hydrography, Terr. Atmos. Ocean. Sc., 3, 243-275, 1992.

McClain, E. P., Pichel, W. G., and Walton, C. C.: Comparative performance of AVHRR based multichannel sea surface temperatures, J. Geophys. Res., 90, 11587-11601, 1985.

Moore, J. K., Doney, S. C., Glover, D. M., and Fung, I. Y.: Iron cycling and nutrient-limitation patterns in surface waters of the World Ocean, Deep-Sea Res. (II Top. Stud. Oceanogr.), 49, 463507, 2002.

Redfield, A. C., Ketchum, B. H., and Richard, F. A.: The influence of organisms on the composition of seawater, in: The Sea, edited 
by: Hill, M. N., Interscience, New York, 27-77, 1963.

Riemann, B., Simonsen, P., and Stensgaard, L.: The carbon and chlorophyll content of phytoplankton from various nutrient regimes, J. Plankton Res., 11, 1037-1045, 1989.

Sathyendranath, S., Platt, T., Horne, E. P. W., Harrison, W. G., Ulloa, O., Outerbridge, R., and Hoepffner, N.: Estimation of new production in the ocean by compound remote sensing, Nature, 353, 129-133, 1991.

Shang, S. L., Li, F. S., Wu, J., Hu, C. , Chen, D., Ning, X., Qiu, Y., Zhang, C., and Shang, S.: Changes of temperature and bio-optical properties in the South China Sea in response to Typhoon Lingling, Geophys. Res. Lett., 35, L10602, doi:10610.11029/12008GL033502, 2001.

Shiah, F. K., Chung, S. W., Kao, S. J., Gong, G. C., and Liu, K. K.: Biological and hydrographical responses to tropical cyclones (typhoons) in the continental shelf of the Taiwan Strait, Contin. Shelf Res., 20, 2029-2044, 2000.

Siswanto, E., Ishizaka, J., Yokouchi, K., Tanaka, K., and Tan, C. K.: Estimation of interannual and interdecadal variations of typhoon-induced primary production: a case study for the outer shelf of the East China Sea, Geophys. Res. Lett., 34, L03604, doi:10.1029/2006GL028368, 2007.

Son, S., Platt, T., Fuentes-Yago, G., Bouman, H., Devred, E., Wu, Y., and Sathyendranath, S.: Possible biogeochemical response to the passage of Hurricane Fabian observed by satellites, J. Plankton Res., 29, 687-697, 2007.

Sverdrup, H. U.: On Conditions for the Vernal Blooming of Phytoplankton, ICES J. Mar. Sci., 18, 287-295, 1953.
Tang, S., Chen, C., Zhan, H., Zhang, J., and Yang, J.: An appraisal of surface chlorophyll estimation by satellite remote sensing in the South China Sea, Internat. J. Remote Sens., 29, 6217-6226, 2008.

Tsai, Y., Chern, C.-S., and Wong, J.: Typhoon induced upper ocean cooling off northeastern Taiwan, Geophys. Res. Lett., 35, L14605, doi:10.1029/2008GL034368, 2008.

Walker, N. D., Leben, R. R., and Balasubramanian, S.: Hurricaneforced upwelling and chlorophyll- $a$ enhancement within coldcore cyclones in the Gulf of Mexico, Geophys. Res. Lett., 32, L18610, doi:10.1029/2005GL023716, 2005.

Webster, P. J., Holland, G. J., Curry, J. A., and Chang, H.-R.: Changes in tropical cyclone number, duration, and intensity in a warming environment, Science, 309, 1844-1846, 2005.

Wei, C.-L. and Hung, C.-C.: Particle scavenging in the upper water column off Mindoro Island, Philippine: ${ }^{234} \mathrm{Th} /{ }^{238} \mathrm{U}$ disequilibrium. Estuarine, Coastal and Shelf Science, 46, 351-358, 1998.

Wu, C.-R., Lu, H.-F., and Chao, S.-Y.: A numerical study on the formation of upwelling off northeast Taiwan, J. Geophys. Res., 113, C08025, doi:10.1029/2007JC004697, 2008.

Zhao, H., Tang, D., and Wang, Y.: Comparison of phytoplankton blooms triggered by two typhoons with different intensities and translation speeds in the South China Sea, Mar. Ecol. Prog. Ser., 365, 57-65, 2008.

Zheng, G. M. and Tang, D. L.: Offshore and nearshore chlorophyll increases induced by typhoon winds and subsequent terrestrial rainwater runoff, Mar. Ecol. Prog. Ser., 333, 61-74, 2007. 